\title{
Effectiveness of hydrothermal pretreatment to rice bran before extraction on physico-chemical qualities of rice bran oil
}

\author{
Minh Phuoc Nguyen \\ Faculty of Biotechnology, Ho Chi Minh City Open University, Ho Chi Minh City, Vietnam \\ *Email: minh.np@ou.edu.vn
}

\author{
ARTICLE HISTORY \\ Received: 12 September 2020 \\ Accepted: 27 October 2020 \\ Published: 08 November 2020 \\ KEYWORDS \\ Acid value \\ Free fatty acid \\ Hydrothermal pretreatment \\ Peroxide value; rice bran oil; \\ tocopherol; yield; $\boldsymbol{\gamma}$-oryzanol
}

\begin{abstract}
Rice bran oil has great benefits over other edible oils due to its unique antioxidant, oryzanol. There are many techniques employed for the extraction of rice bran oil. This research examined the impact of hydrothermal pretreatment $\left({ }^{\circ} \mathrm{C} / \mathrm{min}\right)$ before screw press extraction on physico-chemical quality attributes of rice bran oil such as peroxide value (meq $\mathrm{O}_{2} / \mathrm{Kg}$ oil), acid value ( $\mathrm{mg} \mathrm{KOH} / \mathrm{g}$ oil), free fatty acid (\% olecic acid), tocopherol $(\mu \mathrm{g} / \mathrm{g})$, FRAP ferric reducing antioxidant power ( $\mathrm{mg} \mathrm{FeSO}_{4} / \mathrm{g}$ ), DPPH radical scavenging activity (\%), $\gamma$-oryzanol content $(\mathrm{mg} / \mathrm{g})$ and oil extraction yield (\%). Our results revealed that rice bran should be heated at $120{ }^{\circ} \mathrm{C}$ for $8 \mathrm{~min}$ before screw press extraction to obtain the best physico-chemical and antioxidant qualities of rice bran oil. By this investigation, the economic value of rice bran would be improved significantly as a valuable input for food and pharmaceutical industry, instead of mono utilization as by-product for feed. Consumers would have better chance to improve their health via a green phytochemical food.
\end{abstract}

\section{Introduction}

Agriculture produce animal and plant as raw materials essential for human consumption and other industries (1). Consumers' attitudes and behaviours in the technology-driven sharing economy provided empirical evidence on motivations for participating in collaborative consumption (2). Rice bran is normally considered as a waste from the rice processing factories. Rice bran oil (RBO) is usually received from the outer layer of the brown rice. RBO has a bright colour, translucent appearance, distinct aroma as well as neutral taste. It is a good source of unsaturated fatty acids and free of trans fats. RBO revealed various benefits compared to other edible oils owing to numerous functional elements like tocopherols, $\gamma$ oryzanol and tocotrienols, which are accounted for its oxidative capacity and therapeutic advantages (3-4). The $\beta$-sitosterol, campesterol, stigmasterol, squalene and $\gamma$-oryzanol were identified as phytosterols in RBO (5). The availability of $\quad \gamma$-oryzanol and $\gamma$ tocotrienol in RBO decides a preventive mechanism of a-tocopherol in deep-frying (6). The polyunsaturated fatty acids in this oil contributes to higher hypolipidaemic activities over other edible oils including linoleic acid and thus decreases the cardiovascular risk (7). RBO alleviates the menopausal ailments, enhances the cognitive ability and prevents allergic reactions (8).

The extraction of vegetable oil is commonly done by the application of mechanical force or by solvent extraction. The continuous prototype outperforms the original batch system to interfere the pressure shock waves. Pilot apparatus can not compete with the commercial scale (9). The application of pressure shock waves, together with the mechanical press, may accelerate oil yields, minimize pressing energy requirements while obtaining the similar oil yield, low oil residue in the seed cake, limited volatile substance, less pollution, and more biogas formation (10). In press utilization, pretreatments are very necessary to alter the cellular texture supporting the oil escape and to enhance the extraction recovery (11-12). In a study it was found that hot pressing affected the concentration of unsaturated fatty acids (13). Objective of our study was to examine the influence of hydrothermal pretreatment (110/12, 115/10, 120/8, $125 / 6,130 / 4{ }^{\circ} \mathrm{C} / \mathrm{min}$ ) before screw press extraction on physico-chemical quality attributes such as peroxide

(c) Nguyen (2020). This is an open-access article distributed under the terms of the Creative Commons Attribution License, which permits unrestricted use, distribution and reproduction in any medium, provided the original author and source are credited (https://creativecommons.org/licenses/by/4.0/).

To cite this article: Nguyen M P. Effectiveness of hydrothermal pretreatment to rice bran before extraction on physico-chemical qualities of rice bran oil. Plant Science Today. 2020;7(4):658-662. https://doi.org/10.14719/pst.2020.7.4.953 
value, acid value, free fatty acid, tocopherol, ferric reducing antioxidant power, radical scavenging activity, $\gamma$-oryzanol content and oil extraction yield of rice bran oil. It's urgent to examine the hydrothermal pretreatment so that the best physico-chemical and antioxidant qualities of rice bran oil would be achieved and human health would be improved via utilization of valuable substances in rice bran oil.

\section{Materials and Methods}

Rice bran was collected from rice milling factories in Soc Trang province, Vietnam. After collecting, it was stored at ambient temperature for experiments. All chemical substances were of analytical grade.

\section{Researching method}

Rice bran was treated by dehydration in an air-blast drying machine (power supply: $220 \mathrm{~V} 50 \mathrm{~Hz}$; dimension: $54 * 36 * 35 \mathrm{~cm}$; origin: Jiangsu, China) at 40 ${ }^{\circ} \mathrm{C}$ to a moisture content around $7.0 \%$. The hydrothermal treatment was conducted at $110 / 12$, $115 / 10,120 / 8,125 / 6,130 / 4\left({ }^{\circ} \mathrm{C} / \mathrm{min}\right)$. The pre-treated samples were screw-pressed under a volume of 2.5 $\mathrm{kg} / \mathrm{hr}$. The pressed oil was subjected to clarification by centrifugation at $3000 \mathrm{rpm}$ for $5 \mathrm{~min}$. The collected press oil was stored in dark glass bottle and ready for physico-chemical analysis.

\section{Physico-chemical analysis}

Yield of extraction $=$ rice bran oil $(\mathrm{gm}) \times 100 /$ primary weight of rice bran (gm). $\gamma$-oryzanol content (mg/g extract) of rice bran oil samples were determined by reversed-phase HPLC (14). DPPH (mg/mL) radical scavenging activity was analyzed by DPPH assay (15). FRAP (mg $\mathrm{FeSO}_{4} / \mathrm{gm}$ ) procedure was conducted following the standard protocol (16). Tocopherol ( $\mu \mathrm{g} /$ gm oil), free fatty acid or FFA (\% Oleic acid), acid value or $\mathrm{AV}$ (mg $\mathrm{KOH} / \mathrm{gm}$ oil), peroxide value or PV (meq $\mathrm{O}_{2} / \mathrm{Kg}$ oil) of rice bran oil samples were evaluated by the analyzing standard method (17).

\section{Statistical analysis}

All experiments were set in 3 replications. The presented data were shown as mean \pm standard deviation. Statistical analysis was accounted by the Statgraphics (version 16.2.04, 64-bit).

\section{Results and Discussion}

The yield of rice bran oil in different hydrothermal pretreatments $(110 / 12,115 / 10,120 / 8,125 / 6,130 / 4$ ${ }^{\circ} \mathrm{C} / \mathrm{min}$ ) are shown in Fig. 1 . The highest rice bran oil yield $(7.30 \pm 0.02 \%)$ was obtained by heating rice bran at $120{ }^{\circ} \mathrm{C}$ for $8 \mathrm{~min}$ before screw extraction. There was no significant difference in 120/8, 125/6 and $130 / 4\left({ }^{\circ} \mathrm{C} / \mathrm{min}\right)$ as hydrothermal pretreatment for rice bran. It's obviously noticed that primary thermal treatment of rice bran prior to screw extraction strongly increased extraction yield. Temperature softened the cells and made the oil current in the sample released freely during screw-press. It was proved that thermal treatment at $60{ }^{\circ} \mathrm{C}$ for rice bran prior to screw-press accelerated the recovery from 4.8 to $8.3 \% \mathrm{w} / \mathrm{w}$ (18). In comparison with results

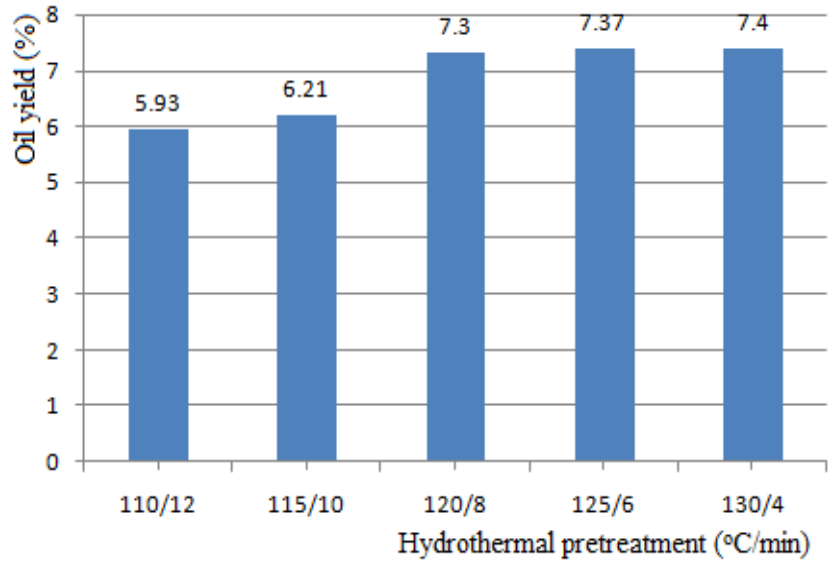

Fig.1. Effect of hydrothermal pretreatment $\left({ }^{\circ} \mathrm{C} / \mathrm{min}\right)$ to rice bran oil yield (\%).

presented by Khongsak and Maythawinee, we successfully achieved a high rice bran oil yield. Hydrothermal pretreatments were demonstrated to enhance antioxidant capacities of rice bran oil (Fig. 2 and 3). There was significant difference of $\mathrm{DPPH}$ $(\mathrm{mg} / \mathrm{mL})$ and FRAP (mg $\mathrm{FeSO}_{4} / \mathrm{gm}$ ) values among hydrothermal pretreatments. The highest DPPH (mg/

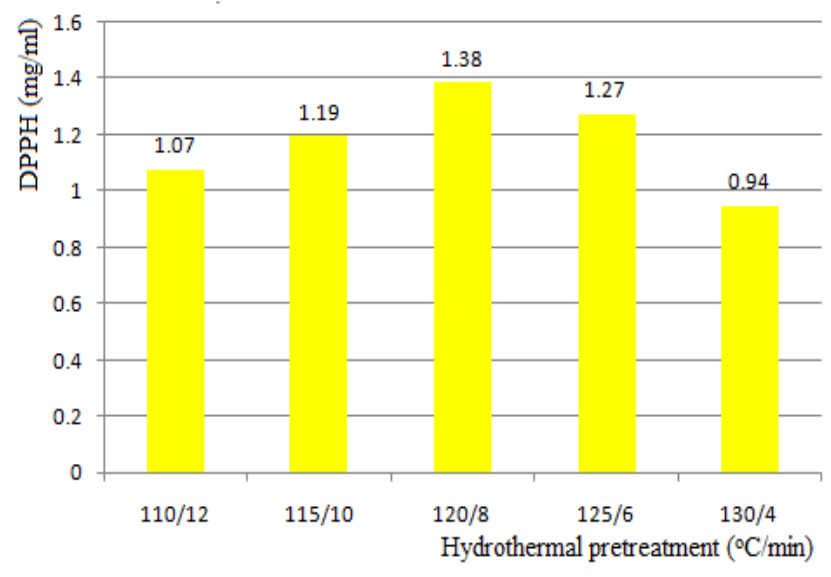

Fig.2. Effect of hydrothermal pretreatment $\left({ }^{\circ} \mathrm{C} / \mathrm{min}\right)$ to $\mathrm{DPPH}$ (mg/ $\mathrm{mL}$ ) in rice bran oil.

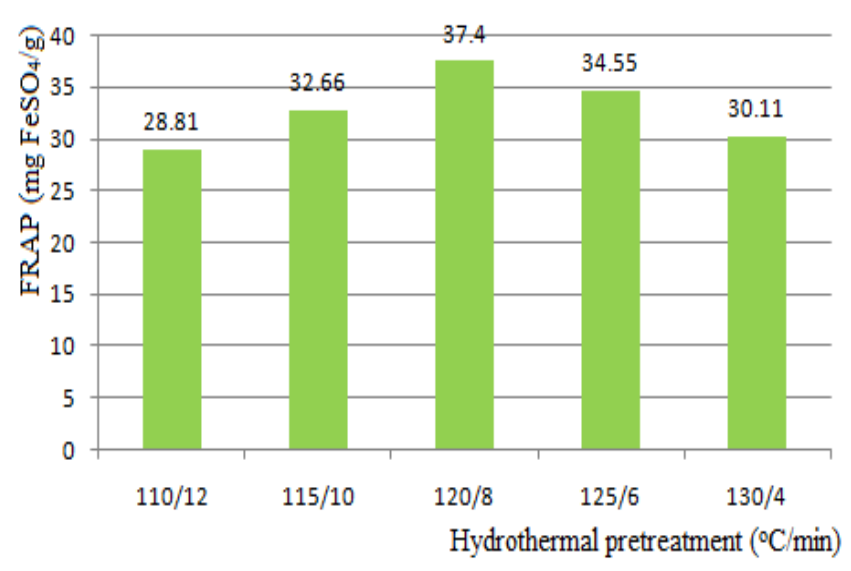

Fig.3. Effect of hydrothermal pretreatment $\left({ }^{\circ} \mathrm{C} / \mathrm{min}\right)$ to FRAP (mg $\left.\mathrm{FeSO}_{4} / \mathrm{gm}\right)$ in rice bran oil.

$\mathrm{mL}$ ) and FRAP (mg $\left.\mathrm{FeSO}_{4} / \mathrm{gm}\right)$ in rice bran oil were obtained at $1.38 \pm 0.01 \mathrm{mg} / \mathrm{mL}$ and $37.4 \pm 0.03 \mathrm{mg} \mathrm{FeSO}_{4} /$ 
gm respectively by heating rice bran at $120{ }^{\circ} \mathrm{C}$ for 8 min before screw extraction. The $\gamma$-oryzanol contents $(\mathrm{mg} / \mathrm{gm})$ and tocopherol $(\mu \mathrm{g} / \mathrm{gm})$ values of rice bran oil by hydrothermal pretreatments were shown (Fig. 4 and 5). There was significant difference among hydrothermal pretreatments. It was obviously noticed that the highest $\gamma$-oryzanol (mg/gm) and

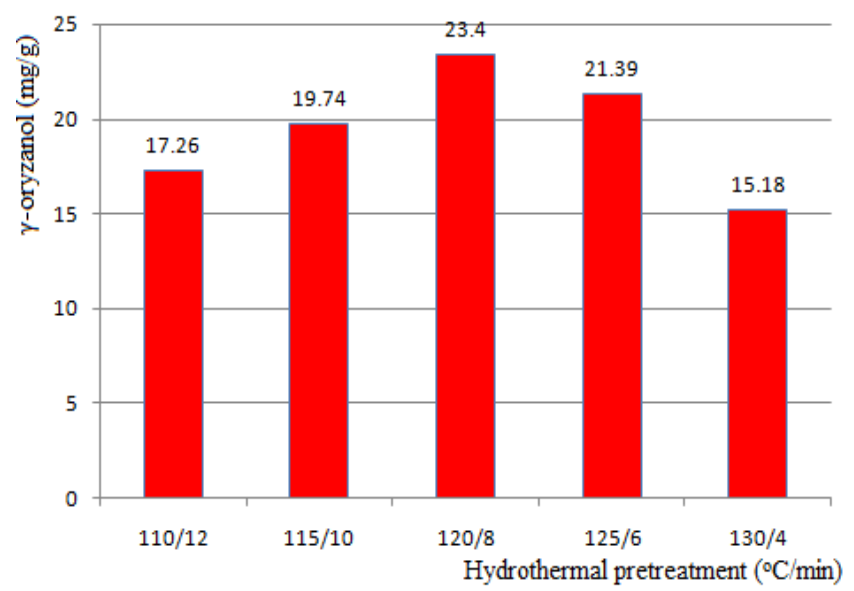

Fig.4. Effect of hydrothermal pretreatment $\left({ }^{\circ} \mathrm{C} / \mathrm{min}\right)$ to $\gamma$-oryzanol $(\mathrm{mg} / \mathrm{gm})$ in rice bran oil.

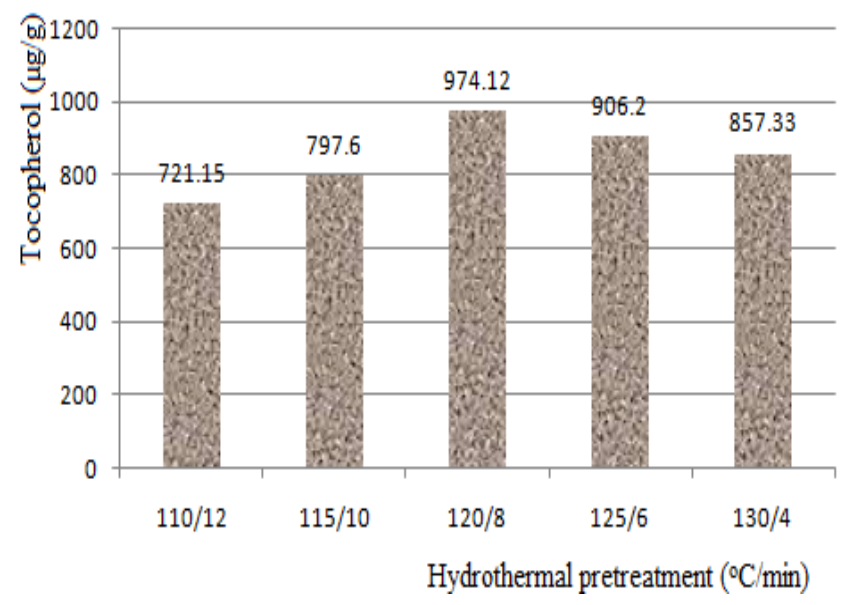

Fig.5. Effect of hydrothermal pretreatment $\left({ }^{\circ} \mathrm{C} / \mathrm{min}\right)$ to tocopherol $(\mu \mathrm{g} / \mathrm{gm})$ in rice bran oil.

tocopherol $(\mu \mathrm{g} / \mathrm{gm})$ in rice bran oil were achieved at $23.4 \pm 0.03 \mathrm{mg} / \mathrm{gm} 974.12 \pm 0.01 \mu \mathrm{g} / \mathrm{gm}$ respectively by heating rice bran at $120{ }^{\circ} \mathrm{C}$ for $8 \mathrm{~min}$ before screw extraction. Gamma-oryzanol, a mixture of triterpene alcohols and plant sterols, was the main composition of rice bran oil (7). Oryzanol was a popular antioxidant help lowering serum and plasma cholesterol, platelet aggregation and cholesterol absorption. It was utilized to cure hyperlipidemia and menopause disorders (19). The free fatty acid and acid value of edible oil was an indicator of hydrolytic rancidity. The lower the values of both FFA and AV the better the quality of the oil and more stable was the oil against hydrolytic rancidity (20). The free fatty acid and acid values of rice bran oil under hydrothermal pretreatments were presented (Fig. 6 and 7). There was minor significant difference among hydrothermal pretreatments. It's obviously noticed that the lowest free fatty acid (\% olecic acid) and acid value (mg $\mathrm{KOH} / \mathrm{gm}$ oil) in rice bran oil were presented at $0.85 \pm 0.00 \%$ and $1.65 \pm 0.02 \mathrm{mg} \mathrm{KOH} / \mathrm{g}$ oil

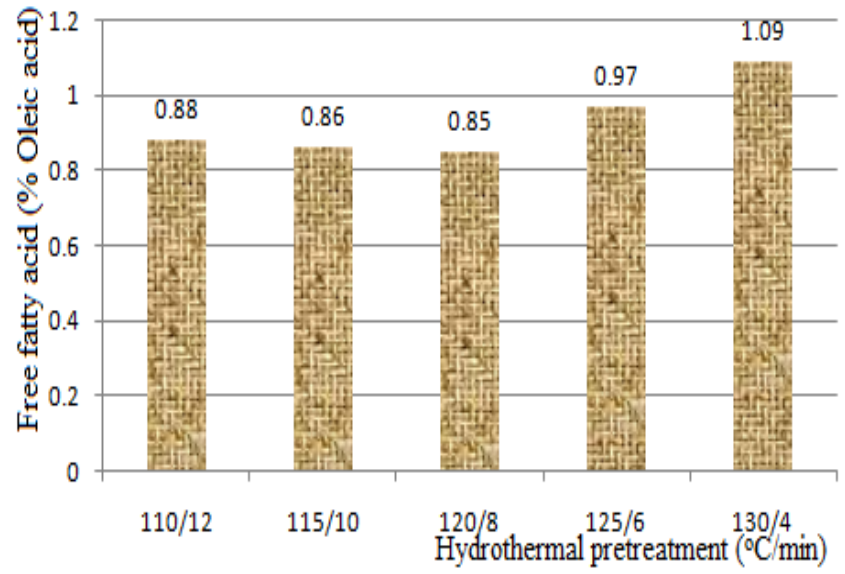

Fig.6. Effect of hydrothermal pretreatment $\left({ }^{\circ} \mathrm{C} / \mathrm{min}\right)$ to free fatty acid (\% Oleic acid) in rice bran oil.

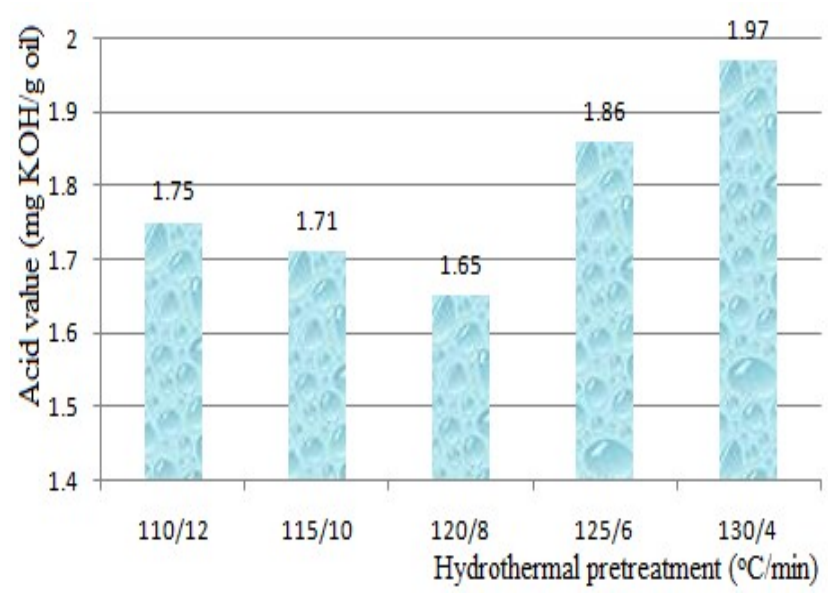

Fig.7. Effect of hydrothermal pretreatment $\left({ }^{\circ} \mathrm{C} / \mathrm{min}\right)$ to acid value (mg KOH/gm oil) in rice bran oil.

respectively by heating rice bran at $120{ }^{\circ} \mathrm{C}$ for $8 \mathrm{~min}$ before screw extraction. Peroxide value (PV) is an important quality indicator of oxidative stability of edible oil (21). The peroxide value (meq $\mathrm{O}_{2} / \mathrm{Kg}$ oil) values of rice bran oil by hydrothermal pretreatments were shown in (Fig. 8). There was significant difference among hydrothermal pretreatments. It's obviously noticed that the lowest

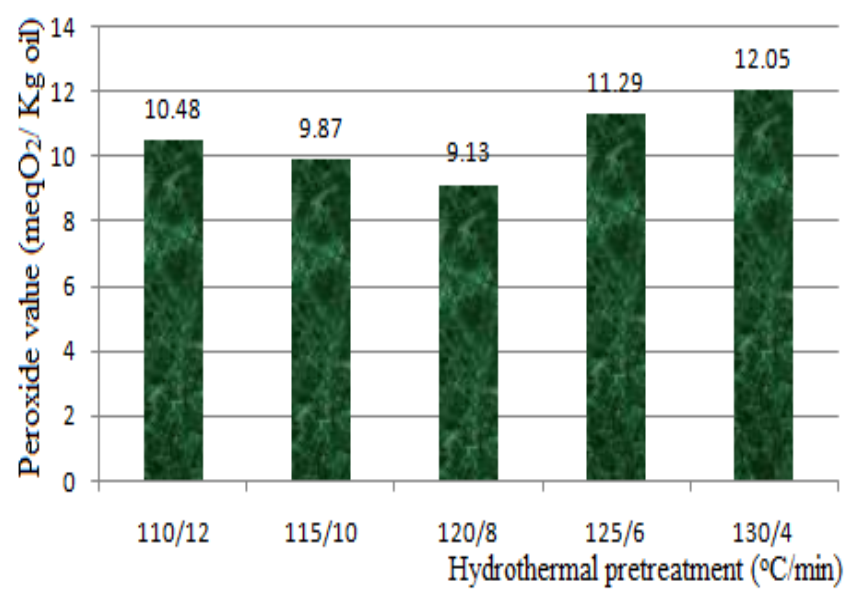

Fig.8. Effect of hydrothermal pretreatment $\left({ }^{\circ} \mathrm{C} / \mathrm{min}\right)$ to peroxide value $\left(\mathrm{meqO}_{2} / \mathrm{Kg}\right.$ oil) in rice bran oil. 
peroxide value $\left(9.13 \pm 0.02\right.$ meq $\mathrm{O}_{2} / \mathrm{Kg}$ oil) in rice bran oil was obtained by heating rice bran at $120{ }^{\circ} \mathrm{C}$ for 8 min before screw extraction. It was proved that temperature in the extraction process strongly affected the value of rice bran oil (22). The influence of hydrothermal-microwave pretreatment in various variables on canola oil expression was examined (23). They proved that seeds pretreated by hydrothermal- microwave at $130{ }^{\circ} \mathrm{C}$ for $2.98 \mathrm{mins}$ obtained maximum canola oil recovery and the highest amount of canolol and the total tocopherol retention. Gasification improved the broken effects of the edges of the pressure waves, inducing to higher lignocellulose decomposition. Cell walls decomposition enhanced oil extraction yield and supported the upcoming anaerobic fermentation of the press cake residue (24). Shockwave pretreatment greatly accelerated the next enzymatic hydrolysis, which finally released the vacuoles rich in oil (25). Disruptive technologies will enable digitization of the processing industry (26). Agriculture development should be build on scientific foundation. Artificial intelligence would be absolutely appreciated as a beneficial strategy for business analyses and forecasting (27).

\section{Conclusion}

Rice bran was utilized to get rice bran oil. Rice bran oil contained high level of physiologically functional constituents. The phytochemical constituents of the rice bran oil were highly associated with its health advantages. Rice bran oil was gaining popularity due to its excellent cooking property to extend longevity and well-balanced fatty acid constituent. In this research, we successfully demonstrated the impact of hydrothermal pretreatment before screw press extraction to physico-chemical quality attributes of rice bran oil. Yield of rice bran oil extracted by screw compression accelerated by thermal treatment of rice bran before the mechanical extraction. This treatment at $120^{\circ} \mathrm{C}$ for $8 \mathrm{~min}$ also improved the oil quality with higher contents of $\gamma$-oryzanol and tocopherol, improved antioxidant capacity, while lowering the levels of free fatty acid, acid value and peroxide value.

\section{Acknowledgements}

We acknowledged the financial support for the publication provided by Ho Chi Minh City Open University, Vietnam.

\section{Authors' contributions}

Minh Phuoc Nguyen arranged the experiments and also wrote the manuscript.

\section{Conflict of interests}

The authors confirmed that this study was conducted without any conflict of interest.

\section{References}

1. Veronika M and Jaromir V. Value generators for businesses in agriculture. The 12th International Days of Statistics and Economics, Prague, September 6-8, 2018. https://msed.vse.cz/msed_2018/article/57-Machova-Veronikapaper.pdf

2. Graessley S, Jakub H, Maria M, Katarína V, Milos P. Consumer attitudes and behaviors in the technology-driven sharing economy: Motivations for participating in collaborative consumption. Journal of Self-Governance and Management Economics. 2019;7:25-30. https://10.22381/JSME7120194

3. Wilson T, Ausman L, Lawton C, Hegsted D, Nicolosi R. Comparative cholesterol lowering properties of vegetable oils: beyond fatty acids. J Am Coll Nutr. 2000;19:601-07. https://doi.org/10.1080/07315724.2000.10718957

4. Kim JS and Godber JS. Oxidative stability and vitamin E levels increased in restructured beef roast with added rice bran oil. J Food Qual. 2001;24:17-26. https://doi.org/10.1111/j.17454557.2001.tb00587.x

5. Nayik AG, Majid I, Gull A, Muzaffar K. Rice bran oil, the future edible oil of India: A mini review. Rice Research: Open Access. 2015;3:4-6. https://doi.org/10.4172/2375-4338.1000151

6. Hamid AA, Dek MS, Tan CP, Zainudin MA, Fang EK. Changes of major antioxidant compounds and radical scavenging activity of palm oil and rice bran oil during deep-frying. Antioxidants. 2014;3:502-15. https://doi.org/10.3390/antiox3030502

7. Friedman M. Rice brans, rice bran oils, and rice hulls: composition, food and industrial uses and bioactivities in humans, animals and cells. J Agric Food Chem. 2013;61:1062641. https://doi.org/10.1021/jf403635v

8. Mehdi BJ, Tabassum S, Haider S, Perveen T, Nawaz A, Haleem DJ. Nootropic and antistress effects of rice bran oil in male rats. J Food Sci Technol. 2015;52:4544-50. https://doi.org/10.1007/s13197-014-1489-1

9. Marousek J. Economic analysis of the pressure shockwave disintegration process. International Journal of Green Energy. 2015;12:1232-35. https://doi.org/10.1080/15435075.2014.895740

10. Marousek J. Use of continuous pressure shockwaves apparatus in rapeseed oil processing. Clean Technologies and Environmental Policy. 2013;15:721-25. https://doi.org/10.1007/s10098-012-0549-3

11. Uquiche E, Jeréz M, Ortíz J. Effect of pretreatment with microwaves on mechanical extraction yield and quality of vegetable oil from Chilean hazelnuts. Innovative Food Science and Emerging Technologies. 2008;9:495-500. https://doi.org/10.1016/j.ifset.2008.05.004

12. Szydłowska-Czerniak A, Karlovits G, Hellner G, Dianoczki C, Szłyk E. Effect of enzymatic and hydrothermal treatments of rapeseeds on quality of the pressed rapeseed oils: Part I: Antioxidant capacity and antioxidant content. Process Biochemistry. https://doi.org/10.1016/j.procbio.2009.07.016

13. Ghazani SM, García-Llatas G, Marangoni AG. Micronutrient content of cold-pressed, hot-pressed, solvent extracted and RBD canola oil: Implications for nutrition and quality. European Journal of Lipid Science and Technology. 2014;116:380-87. https://doi.org/10.1002/ejlt.201300288

14. Chalermpong S, Chaiyavat C, Sunee C, Suttajit M, Sirithunyalug B. Antioxidant and anti-inflammatory activities of gammaoryzanol rich extracts from Thai purple rice bran. Journal of Medicinal Plants Research. 2012;6:1070-77. https://doi.org/10.5897/JMPR11.1247

15. Wahid H, Habib K, Sadok B. Physicochemical properties and antioxidant activity of Tunisian date palm (Phoenix dactylifera L.) oil as affected by different extraction methods. Food Science and Technology. 2014;34:464-70. https://doi.org/10.1590/1678-457x.6360

16. Suwannalert P, Rattanachitthawat S, Chaiyasut C, Riengrojpitak S. High levels of 25-hydroxyvitamin D [25(OH) D3] and ${ }_{3} \alpha$-tocopherol prevent oxidative stress in rats that consume Thai brown rice. Journal of Medicinal Plants Research. 2010;4:120-24._http://dx.doi.org/10.4314/tjpr.v10i4.8 
17. AOCS. Official and Tentative Method of the American Oil Chemists Society, ( $5^{\text {th }}$ edn) Published by American Oil Chemists Society Champaign II, USA. Method cd 2004;8:53.

18. Khongsak S and Maythawinee P. Simple techniques to increase the production yield and enhance the quality of organic rice bran oils. Journal of Oleo Science. 2011;60:1-5. https://doi.org/10.5650/jos.60.1

19. Patel M, Naik SN. Gamma-oryzanol from rice bran oil: a review. Journal of Scientific and Industrial Research 2004;63:569-78.

http://nopr.niscair.res.in/bitstream/123456789/5457/1/JSIR \%2063(7)\%20569-578.pdf

20. Arawande JO, Amoo IA. Stability studies on refined soybean oil stored in various conditions. Pakistan Journal of Scientific and Industrial 2009;52:303-06. https://www.researchgate.net/publication/279568052_Stability studies_on_refined_soybean_oil_stored_in_various_conditions

21. Arawande JO, Komolafe EO, Shakpo IO. Effect of citric acid and storage containers on keeping quality of refined soybean oil. Pakistan Journal of Scientific and Industrial Research. 2011;54:40-44. https://v3.pjsir.org/index.php/physical-sciences/ article/view/175

22. Pengkumsri N, Chaiyasut C, Sivamaruthi BS, Saenjum C, Sirilun S, Peerajan S, Suwannalert P, Sirisattha S, Chaiyasut K, Kesika $P$. The influence of extraction methods on composition and antioxidant properties of rice bran oil. Food Science and Technology. 2015;35:493-501. https://doi.org/10.1590/1678457X.6730
23. Cortese CM, Portela G, Sanchez RJ. Exploring the effect of combined hydrothermal-microwave pretreatment operating conditions on canola oil expression. J Food Technol Pres. 2017;1:1-6. https://www.alliedacademies.org/articles/exploringthe-effect-of-combined-hydrothermalmicrowave-pretreatmentoperating-conditions-on-canola-oil-expression-9077.html

24. Marousek J. Novel technique to enhance the disintegration effect of the pressure waves on oilseeds. Industrial Crops and Products. 2014;53:1-5. https://doi.org/10.1016/j.indcrop.2013.11.048

25. Marousek J, Haskova S, Marouskova A, Myskova K, Vanickova R, Vachal J, Vochozka M, Zeman R, Zak J. Financial and biotechnological assessment of new oil extraction technology, energy sources, Part A: Recovery, utilization and environmental effects 2015;37:1723-28. https://doi.org/10.1080/15567036.2015.1048391

26. Eilis B, Maria K, Jana K, Zuzana R. Smart industrial internet of things devices, services and applications: ubiquitous sensing and sensory data, predictive analytics algorithms and cognitive computing technologies. Analysis and Metaphysics. 2019;18:50-56. https://doi.org/10.22381/AM1820197

27. Vojtěch S, Jakub H, Marek V. Prediction of institutional sector development and analysis of enterprises active in agriculture. Business Administration and Management. 2019;4:103-18. https://doi.org/10.15240/tul/001/2019-4-007 